\title{
Electromagnetic Effect on Vitality and Activity of Honey Bees in El- Beheira Governorate, Egypt
}

\author{
Mesbah, H.A., A.K. Morad, N.A. EL-Sayed, M. E. Morsy and G.A. EL-Hamamy ${ }^{1}$
}

\begin{abstract}
The present study was initiated to find out the electromagnetic effect on the vitality and activity of honey bees during May 2019 at Abo-Hommos, El-Beheira Governorate. For that goal 15 colonies were selected same strength and divided into five groups, each group comprised 3 colonies. Each of these groups was placed at various distances of a high-pressure electric tower $220 \mathrm{KV}$ $(100,300,400,500$, and $550 \mathrm{~m})$. The results obtained showed an increase in the number of honey bee workers leaving the placed hives at a distance of 100 meters from the high-pressure electric tower, vice versa numbers of bee workers, gradually decreased to reach the normal number in case of ascendingly moved hives away from the highpressure electric tower $(65.3 \mathrm{bees} /$ minute at a distance of 100 meters, 61.36 at 300 meters, 58.5 at $400 \mathrm{~m}, 53.2$ at $500 \mathrm{~m}$, and 50.33 at $550 \mathrm{~m}$ ) compared to the normal one of 50 bees/minute at $2000 \mathrm{~m}$ ). In contrast, the counted number of returned honey bee workers to their hives decreased dependingly on the distance apart of the high-pressure electric tower $(35.16$ bees/minute at a distance of $100 \mathrm{~m}$, 37.66 at $300 \mathrm{~m}, 39.66$ at $400 \mathrm{~m}, 44.5$ at $500 \mathrm{~m}, 51.03$ at $550 \mathrm{~m}$, compared to the normal rate of 51.3 bees/minute at $2000 \mathrm{~m})$. On the other hand, it was observed that the queens were affected, as they lessened their deposited eggs; expressed by the capped brood area in square inches. When the hive was nearer to the electrical tower the capped brood area comprised 18.83 square inches/hive at a distance of $100 \mathrm{~m}, 23.03$ at $300 \mathrm{~m}, 26.7$ at $400 \mathrm{~m}, 26.9$ at $500 \mathrm{~m}$, and 31 at $550 \mathrm{~m}$; compared to the normal rate of 31 square inches/hive at $2000 \mathrm{~m}$. In contrast, the numerical density of the colony was also affected, and expressed by the number of frames covered with bees, and the drastic electromagnetic effect was evident on the distance of located hives near to the high-pressure electric tower (5 frames at a distance of $\mathbf{1 0 0}$ meters, 6 frames at $\mathbf{3 0 0}$ meters, 7 frames at 400 meters, 7.66 frames at 500 meters, 8 frames at 550 meters, compared to the normal average of 8 frames/hive at $2000 \mathrm{~m}$ ).
\end{abstract}

Keywords: Electromagnetic (EMF), Honeybee, Highpressure electric tower.

\section{INTRODUCTION}

Very simply, electromagnetic fields (EMFs) are invisible lines of magnetic force that emanate from frequencies with electric and magnetic properties. There are natural sources of EMFs, from things like lightning and sunlight, and there are unnatural EMFs that are produced by man-made electricity and wireless communications.

A decline of pollinator species can significantly compromise agricultural production (Gallai et al. 2009 and Breeze et al. 2014). Bees contribute approximately $80 \%$ of insect pollination, making it crucial to understand and mitigate the causes of current population declines (Potts et al. 2010). Honeybees use the magnetic field of the earth to determine their direction. Nowadays, the rapid spread of electrical devices and mobile towers leads to an increase in man-made EMF. This maybe causes honeybees to lose their orientation and thus lose their hives. EMF exposure was found to reduce learning, alter flight dynamics, and reduce the success of foraging flights towards food sources and feeding (Gallai et al. 2009). The results of the author (Mrgdal et al. 2021). suggest that $50 \mathrm{~Hz}$ ELF- EMFs emitted from power lines may represent a prominent environmental stressor for honey bees, with the potential to impact their cognitive and motor abilities, which could, in turn, reduce their ability to pollinate crops. The impacts of different stressors on pollination ecosystem services, particularly when in combination, are currently poorly understood. Improving this situation, and defining solutions have been identified as one of the most important, and complex, global challenges to reduce pollinator decline. The aim of this work is to study the effect of electro-magnetic waves on the vitality and activity of honey bees.

\section{MATERIALS AND METHODS}

This experiment was conducted during May 2019 at Abo-Hommos, El-Beheira Governorate; 15 colonies were with equal strength and the same age as the queens and divided into five groups, and each group implied 3 colonies. The first group was placed at 100 meters from the high-pressure electric tower $220 \mathrm{KV}$, the second at 300 meters, the third, fourth, and fifth groups were placed at 400, 500, and 550 meters, respectively.

The experiment lasted for 30 days, and the results were taken every 3 days as follows:

1 - Counting the mean number of bee workers leaving the hive at 12 noon for 10 minutes. 
2 - Counting the mean number of bee workers returning to the hive at 12 noon for 10 minutes.

3 - Measuring the mean area of the capped brood in square inches as an indication of the rate of laying eggs by the queen.

4- Estimating the mean of the increase of bee density (frame/hive) after the end of the experiment,

The outgoing and returning bee workers were counted by making two openings for the entrance of the hive, one for the exit of the bees. a funnel was placed on it to catch and hold the bees in it, and the second opening for the entry of the returning bees was placed on it another funnel was placed to keep the bees in it until it was counted after 10 minutes.

\section{Statistical Analysis}

Using "F" and "L.S.D." tests were performed for the comparison and evaluation of the tested materials. Data were subjected to the analysis of variance test (ANOVA) with mean separation at 5\% levels of significance. Computer programs IRRISTAT and duncan's Multiple Range test were used to compare the averages of detected results according to the method of Snedecor and Cochran (1967).

\section{RESULTS AND DISCUSSION}

The effect of radiation stress and electromagnetic field on the vitality and activity of honey bees

The demonstrated results in the tables from lup4 show the effect of electromagnetic waves on the vitality and bee's activity.

\section{Leaving bee workers the hive}

The included results in Table (1) show that whenever the location of the apiary is close to a highpressure electric tower, the more affects the rate of leaving the workers their hive, because of being affected by the electromagnetic waves., As the rate of leaving of the workers from their hives was severely affected at a distance of 100 meters away - 65.3 bees/minute, followed by 61.36 bees/minute at 300 meters, 58.5 bees/minute at 400 meters away, and 53.2 bees/minute at 500 meters, while 550 meters away was less effective on leaving bees 50.33 bees/minute, compared to the average normal leaving 51.3 bees/minute at $2000 \mathrm{~m}$.

\section{Returning bee workers to their hive}

From the results presented in Table (2) it is clear that the closer place of the apiary to a high-pressure electric tower, caused the lower rate of returning of the workers to the hives due to being highly affected by the electromagnetic waves, which leads to their disorientation and inability to recognize the location of their hives, as the rate of returning of workers to their hives amounted to 35.16 bees/minute at 100 meters away, 37.66 bees/minute at 300 meters, 39.66 bees/minute at 400 meters, 44.5 bees/minute at 500 meters, and 50.33 bees/minute at 550 meters away, compared to the average normal returning rate of 50 bees/minute at $2000 \mathrm{~m}$.

\section{The queen's egg-laying rate}

Table (3) clearly show the efficacy of the proximity and location of the apiary to a high-pressure electric tower on the rate of laid eggs by the queen, which is estimated by the mean area of the capped brood in square inches. The rate of queen's egg-laid amounted to 18.83 square inches/hive at a distance of 100 meters away, 23.03 square inches/hive at 300 meters, (26.7 square inches/hive) at 400 meters away, (26.9 square inches/hive) at 500 meters away, and 31 square inches/hive at a distance of 550 meters away, compared to the normal average of 31 square inches/hive at $2000 \mathrm{~m}$.

\section{The density of bees inside their hives}

From the results presented in Table (4), it could be seen, the higher extent of inspected damage to apiaries as a result of transporting them to a location at close area, to an electromagnetic field. Where the proximity to the electromagnetic field caused an increase in the rate of the workers leaving their hive (Table 1) with a decrease in the rate of their return to their hives (Table 2). In addition to the decrease in the rate of laid eggs (Table 3), all of the above-mentioned findings lead to the decrease of the density numbers of bees in the colonies; estimated by the number of covered frames with bees, which was 5 frames /hive at a distance of 100 meters away, 6 frames /hive at 300 meters, 7 frames /hive at 400 meters, 7.66 frames /hive at 500 meters, and 8 frames /hive at 550 meters away, compared to a normal average of 8 frames /hive at $2000 \mathrm{~m}$. 
Table 1. Effect of the electromagnetic field on the bee's workers leaving the hive

\begin{tabular}{|c|c|c|c|c|c|c|c|c|c|}
\hline \multirow{3}{*}{ During exposure } & \multicolumn{6}{|c|}{ Distance } & \multirow{3}{*}{ G. mean of interval } & \multirow{3}{*}{ LSD $_{0.05}$} & \multirow{3}{*}{ Significant } \\
\hline & $100 \mathrm{~m}$ & $300 \mathrm{~m}$ & $400 \mathrm{~m}$ & $500 \mathrm{~m}$ & $550 \mathrm{~m}$ & Normal & & & \\
\hline & \multicolumn{6}{|c|}{ Mean numbers of bees workers leaving the hive } & & & \\
\hline 3 days & $53^{\mathrm{f}}$ & $53.66^{\mathrm{h}}$ & $52^{\mathrm{h}}$ & $50.66^{\mathrm{c}}$ & 50.33 & 51.33 & $51.61^{\mathrm{i}}$ & \multirow{10}{*}{0.55} & \multirow{10}{*}{$* * *$} \\
\hline 6 days & $56.33^{\mathrm{f}}$ & $55.66^{\mathrm{g}}$ & $52.66^{\mathrm{gh}}$ & $52^{\mathrm{bc}}$ & 50.33 & 51.33 & $52.83^{\mathrm{h}}$ & & \\
\hline 9 days & $60.33^{\mathrm{e}}$ & $57.33^{\mathrm{g}}$ & $54.66^{\mathrm{fg}}$ & $52.66^{\mathrm{ab}}$ & 50.33 & 51.33 & $54.22^{\mathrm{g}}$ & & \\
\hline 12 days & $63^{\mathrm{e}}$ & $59.66^{\mathrm{f}}$ & $56^{\mathrm{ef}}$ & $52.66^{\mathrm{ab}}$ & 50.33 & 51.33 & $55.27^{\mathrm{f}}$ & & \\
\hline 15 days & $67^{\mathrm{d}}$ & $61^{\mathrm{ef}}$ & $58.33^{\text {de }}$ & $53^{\mathrm{ab}}$ & 50.66 & 51.66 & $56.66^{\mathrm{e}}$ & & \\
\hline 18 days & $67.66^{\mathrm{cd}}$ & $62^{\mathrm{de}}$ & $59.66^{\mathrm{cd}}$ & $53^{\mathrm{ab}}$ & 50.33 & 51.33 & $57.11^{\mathrm{e}}$ & & \\
\hline 21 days & $69.33^{\mathrm{bcd}}$ & $63.33^{\mathrm{cd}}$ & $61.33^{\mathrm{bc}}$ & $54^{\mathrm{a}}$ & 50 & 51 & $58^{\mathrm{d}}$ & & \\
\hline 24 days & $71^{\mathrm{abc}}$ & $65^{\mathrm{bc}}$ & $62^{\mathrm{bc}}$ & $54.33^{\mathrm{a}}$ & 50.33 & 51.33 & $58.77^{\mathrm{c}}$ & & \\
\hline 27 days & $72^{\mathrm{ab}}$ & $66.66^{\mathrm{b}}$ & $63.33^{\mathrm{ab}}$ & $54.33^{\mathrm{a}}$ & 50.33 & 51.33 & $59.44^{\mathrm{b}}$ & & \\
\hline 30 days & $73.33^{\mathrm{S}}$ & $69.33^{\mathrm{a}}$ & $65^{\mathrm{a}}$ & $53.66^{\mathrm{ab}}$ & 50.66 & 51.33 & $60.55^{\mathrm{a}}$ & & \\
\hline $\mathrm{LSD}_{0.05}$ & 3.55 & 1.96 & 2.34 & 1.61 & N.S & N.S & & & \\
\hline Significant & $* * *$ & $* * *$ & $* * *$ & $* *$ & & & & & \\
\hline G. mean of D. & $65.3^{\mathrm{a}}$ & $61.36^{\mathrm{b}}$ & $58.5^{\mathrm{c}}$ & $53.2^{\mathrm{d}}$ & $50.33^{\mathrm{e}}$ & $50^{\mathrm{e}}$ & & & \\
\hline $\mathrm{LSD}_{0.05}$ & \multirow{2}{*}{\multicolumn{6}{|c|}{$\begin{array}{l}0.62 \\
* * *\end{array}$}} & & & \\
\hline Significant & & & & & & & & & \\
\hline
\end{tabular}


Table 2. Effect of the electromagnetic field on bee's workers returning to their hive

\begin{tabular}{|c|c|c|c|c|c|c|c|c|c|}
\hline \multirow[b]{2}{*}{ During exposure } & \multicolumn{6}{|c|}{ Distance } & \multirow[b]{2}{*}{ G. mean of interval } & \multirow[b]{2}{*}{$\mathbf{L S D}_{0.05}$} & \multirow[b]{2}{*}{ Significant } \\
\hline & $100 \mathrm{~m}$ & $300 \mathrm{~m}$ & $400 \mathrm{~m}$ & $500 \mathrm{~m}$ & $550 \mathrm{~m}$ & Normal & & & \\
\hline 3 days & $48^{\mathrm{a}}$ & $48.33^{\mathrm{a}}$ & $48^{\mathrm{a}}$ & $48.66^{\mathrm{a}}$ & 50.33 & 51.33 & $48.88^{\mathrm{a}}$ & & \\
\hline 9 days & $41.33^{\mathrm{b}}$ & $43.33^{\mathrm{b}}$ & $46^{\mathrm{b}}$ & $47.33^{\mathrm{ab}}$ & 50.33 & 51.33 & $46.38^{\mathrm{c}}$ & & \\
\hline 12 days & $38.66^{\mathrm{c}}$ & $40.66^{c}$ & $43.66^{\mathrm{c}}$ & $46.66^{\mathrm{ab}}$ & $5 r .33$ & $5 \cdot .33$ & $45^{\mathrm{d}}$ & & \\
\hline 15 days & $33.33^{\mathrm{d}}$ & $38.33^{\mathrm{cd}}$ & $41^{\mathrm{d}}$ & $45.33^{\mathrm{bc}}$ & 50.33 & 51.33 & $43.05^{\mathrm{e}}$ & & \\
\hline 24 days & $29.33^{\text {ef }}$ & $31.66^{\mathrm{ef}}$ & $34^{\mathrm{g}}$ & $41.33^{\mathrm{d}}$ & 50.33 & 51.33 & $39.44^{\mathrm{h}}$ & & \\
\hline 27 days & $27.33^{\mathrm{fg}}$ & $29.33^{\mathrm{fg}}$ & $31.66^{\mathrm{h}}$ & $40.66^{\mathrm{d}}$ & $5 r .33$ & $5 \cdot .33$ & $38.22^{\mathrm{i}}$ & & \\
\hline 30 days & $26.33^{\mathrm{g}}$ & $27.66^{\mathrm{g}}$ & $29.33^{\mathrm{i}}$ & $40.33^{\mathrm{d}}$ & 50.33 & 51.33 & $37.33^{\mathrm{i}}$ & & \\
\hline $\mathrm{LSD}_{0.05}$ & 2.44 & 2.40 & 1.83 & 1.94 & N.S & N.S & & & \\
\hline Significant & $* * *$ & $* * *$ & $* * *$ & $* * *$ & & & & & \\
\hline
\end{tabular}


Table3. Effect of the electromagnetic field at queen's egg-laying rate/day (inch2)

\begin{tabular}{|c|c|c|c|c|c|c|c|c|c|}
\hline \multirow[b]{2}{*}{ During exposure } & \multicolumn{6}{|c|}{ Distance } & \multirow{3}{*}{ G. mean of interval } & \multirow{3}{*}{ LSD $_{0.05}$} & \multirow{3}{*}{ Significant } \\
\hline & $100 \mathrm{~m}$ & $300 \mathrm{~m}$ & $400 \mathrm{~m}$ & $500 \mathrm{~m}$ & $550 \mathrm{~m}$ & Normal & & & \\
\hline & \multicolumn{6}{|c|}{ Mean area of the capped brood in square inches } & & & \\
\hline 3 days & $28.33^{\mathrm{a}}$ & $28.66^{\mathrm{a}}$ & $29.33^{\mathrm{a}}$ & $30^{\mathrm{a}}$ & 30.66 & 31.66 & $29.5^{\mathrm{a}}$ & & \\
\hline 6 days & $26.66^{\mathrm{ab}}$ & $27.33^{\mathrm{ab}}$ & $28.33^{\mathrm{ab}}$ & $29^{\mathrm{ab}}$ & 30.33 & 31.33 & $28.61^{\mathrm{b}}$ & & \\
\hline 9 days & $24.33^{\mathrm{bc}}$ & $26.66^{\mathrm{b}}$ & $28^{\mathrm{abc}}$ & $28.33^{\mathrm{b}}$ & 30.66 & 31.66 & $28^{c}$ & & \\
\hline 12 days & $22.33^{\mathrm{c}}$ & $25.66^{\mathrm{bc}}$ & $27.33^{\mathrm{abcd}}$ & $27.66^{\mathrm{bc}}$ & 30.33 & 31.33 & $27.22^{\mathrm{d}}$ & & \\
\hline 15 days & $19^{\mathrm{d}}$ & $24.33^{\text {cd }}$ & $27.33^{\mathrm{abcd}}$ & $26.66^{\mathrm{cd}}$ & 31 & 32 & $26.38^{\mathrm{e}}$ & & \\
\hline 18 days & $17.33^{\mathrm{d}}$ & $22.66^{\mathrm{de}}$ & $26.66^{\text {bcde }}$ & $26.33^{\mathrm{cd}}$ & 31 & 32 & $25.66^{\mathrm{f}}$ & & \\
\hline 21 days & $14.66^{\mathrm{e}}$ & $21.33^{\mathrm{ef}}$ & $26^{\text {cde }}$ & $25.33^{\mathrm{de}}$ & 31 & 32 & $24.72^{\mathrm{g}}$ & 0.41 & $* * *$ \\
\hline 24 days & $13.33^{\text {ef }}$ & $19.66^{\mathrm{fg}}$ & $25.66^{\mathrm{def}}$ & $24.66^{\mathrm{ef}}$ & 31.33 & 32 & $24.11^{\mathrm{h}}$ & & \\
\hline 27 days & $12^{\mathrm{fg}}$ & $18^{\mathrm{g}}$ & $24.66^{\mathrm{ef}}$ & $23.66^{\mathrm{fg}}$ & 31.33 & 32.33 & $23.27^{\mathrm{i}}$ & & \\
\hline 30 days & $10.33^{\mathrm{g}}$ & $16^{\mathrm{h}}$ & $23.66^{\mathrm{f}}$ & $22.66^{\mathrm{g}}$ & 31.33 & 32.33 & $22.33^{\mathrm{i}}$ & & \\
\hline $\mathrm{LSD}_{0.05}$ & 2.38 & 1.83 & 1.99 & 1.39 & N.S & N.S & & & \\
\hline Significant & $* * *$ & $* * *$ & $* * *$ & $* * *$ & & & & & \\
\hline G. mean of D. & $18.83^{\mathrm{e}}$ & $23.03^{\mathrm{d}}$ & $26.7^{c}$ & $26.9^{c}$ & $31^{\mathrm{a}}$ & $31^{\mathrm{a}}$ & & & \\
\hline $\operatorname{LSD}_{0.05}$ & & & & & & & & & \\
\hline Significant & & & & & & & & & \\
\hline
\end{tabular}


Table 4. Effect of the electromagnetic field at the numerical density inside their hives

\begin{tabular}{cc}
\hline Distance & $\begin{array}{c}\text { Mean number of covered frames } \\
\text { with bees } \\
\text { (frame/hive) }\end{array}$ \\
\hline $100 \mathrm{~m}$ & $5^{\mathrm{e}}$ \\
$300 \mathrm{~m}$ & $6^{\mathrm{c}}$ \\
$400 \mathrm{~m}$ & $7^{\mathrm{b}}$ \\
$500 \mathrm{~m}$ & $7.66^{\mathrm{a}}$ \\
$550 \mathrm{~m}$ & $8^{\mathrm{a}}$ \\
Normal & $8^{\mathrm{a}}$ \\
LSD $_{0.05}$ & 0.41 \\
Significant & $* * *$ \\
\hline
\end{tabular}

In contrast to our obtained results, the different performed studies in different regions of the world had reported the negative effect of emitted EMF from cell phone towers, high voltage wires, and various electronic devices on honey bees with regard to strength, navigation, behavior, honey store, pollen store, and brood area, etc. our findings are in agreement with those reported by Harst et al., 2006; Sharma and Kumar, 2010; Stefan et al., 2013; Pereira-Bomfim et al. 2015.

In addition, the run studies on the effects of electromagnetic fields on honey bees had shown that initiation or/and cessation of foraging, i.e., the number of incoming foragers are negatively affected (Harst et al., 2006; Kimmel et al., 2007; Stefan et al., 2013; Sharma and Kumar, 2010; Pattazhy, 2011; Darney et al., 2016; Taye et al. 2017), as well as the number of outgoing foragers (Valberg, 2010; Sharma and Kumar, 2010); the successful return of marked feeders (Harst et al., 2006; Stefan et al., 2013).

\section{REFERENCE}

Breeze, T.D., B.E. Vaissière, R. Bommarco, T. Petanidou, N. Seraphides, L. Kozák, J. Scheper, J.C. Biesmeijer, D. Kleijn, S. Gyldenkærne, M. Moretti and A. Holzschuh. 2014. Agricultural policies exacerbate honeybee pollination service supply-demand mismatches across Europe. PLoS One 9. e82996.

Darney, K., A. Giraudin, R. Joseph, P. Abadfie, P. Aupinel, A. Decourtye, E.L. Bourg and M. Gauthier. 2016. Effect of high-frequency radiations on survival of the honeybee (Apis mellifera L.). Apidologie. 47: 703-710.

Gallai, N., J.M. Salles, J. Settele and B.E. Vaissière. 2009.Economic valuation of the vulnerability of world agriculture confronted with pollinator decline. Ecol. Econ. 68: 810-821.

Harst, W., J. Kuhn and H. Stever. 2006. Can electromagnetic exposure cause a change in behaviour? Studying possible non-thermal influences on honey bees: an approach within the framework of educational informatics. Acta Syst. Int. J. 6(1): 1-6.

Kimmel, S., J. Kuhn, W. Harst and H. Stever. 2007.Effect of electromagnetic exposition on the behaviour of the honey bees (Apis mellifera). Acta Syst. Int. J. 1-6pp.

Migdał ,P., A. Murawska, P. Bieńkowski, E. Berbeć and A. Roman. 2012. Changes in Honeybee Behavior Parameters under the Influence of the E-Field at $50 \mathrm{~Hz}$ and Variable Intensity. Animals.11:1-12.

Pattazhy, S. 2011. Electromagnetic radiation (EMR) clashes with honeybees. Department of Zoology, S N College, Punalur, Kerala, India. J. of Entomology and Nematology. 4(1):1-3.

Pereira-Bomfim, M.G.C., W.F. Antonialli-Junior and A.D. Avalos. 2015. Effect of magnetic field on the foraging rhythm and behavior of the swarm-founding paper wasp Polybia paulista Ihering (Hymenoptera: Vespidae). Sociobiology. 62:99-104.

Potts, S.G., J.C. Biesmeijer, C. Kremen, P. Neumann, O. Schweiger and W.E. Kunin. 2010.Global pollinator declines: trends, impacts and drivers. Trends Ecol. Evol. 25: 345-353.

Sharma, V.P. and N.R. Kumar. 2010. Changes in honeybee behaviour and biology under the influence of cell phone radiations. Current Sci. 98(10): 1376-1378.

Snedecor, G.W. and W.G. Cochran. 1967. Statistical Methods. 6th Edn., Oxford and IBH Publishing Co. Pvt. Ltd., New Delhi, India. P.593.

Stefan, M.K., S. Matthias, K. Wilhelm and M. Andrea. 2013. Radiation hydrodynamics integrated in the PLUTO code. Institute for Astronomy and Astrophysics, Section Computational Physics. Eberhard Karls University. Tubingen .10:D-72076.

Taye, R.R., M.K. Deka, A. Rahman and M. Bathari. 2017. Effect of electromagnetic radiation of cell phone tower on foraging behaviour of Asiatic honey bee, Apis cerana F. (Hymenoptera: Apidae), J Entom Zool Studies. 5(3):1527-1529.

Valberg, P. A. 2010.Summary of potential effects of 345-kv power-line electric and magnetic fields (EMFs) on honeybee hives and honeybee behavior. Prepared for: CapX2020. 20 University Road Cambridge, MA. 1-8. 


\section{الملخص العربي}

\section{التأثير الكهرومغناطيسي على حيوية ونثاط نحل العسل في محافظة البحيرة ، مصر}

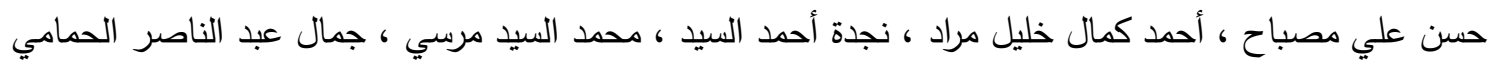

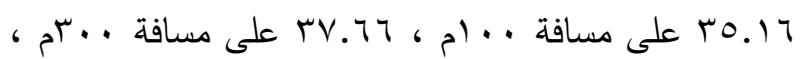

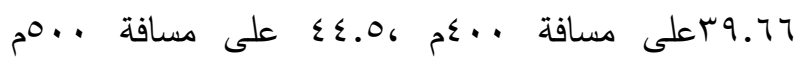

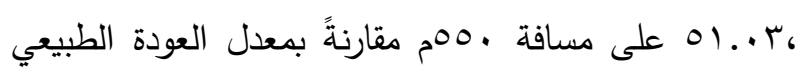

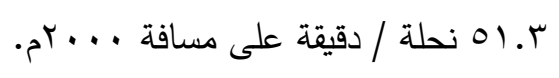

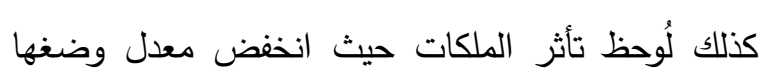

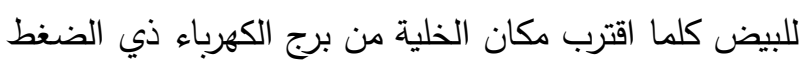

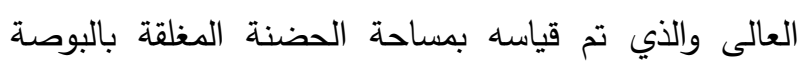

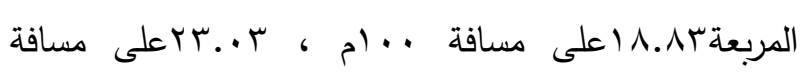

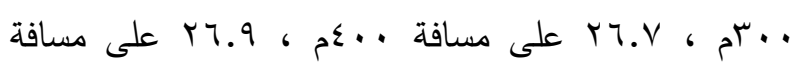

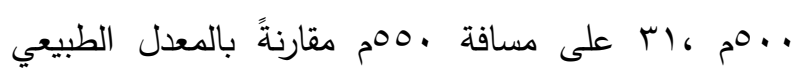

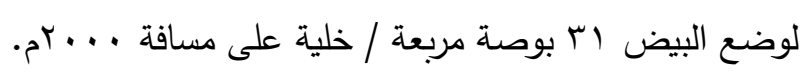

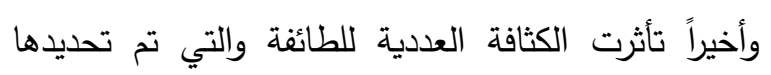

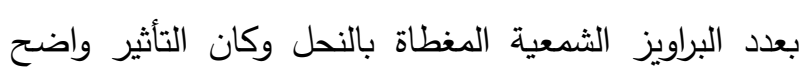

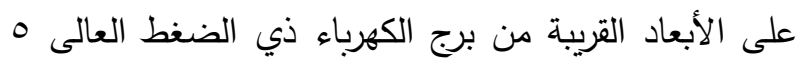

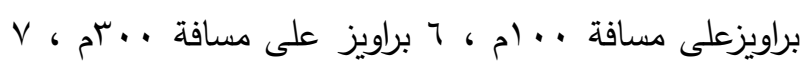

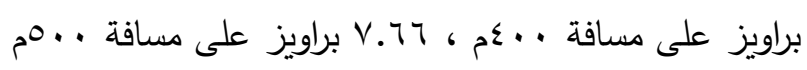

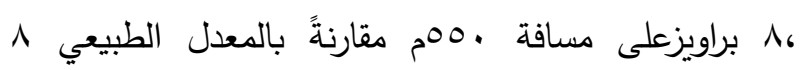

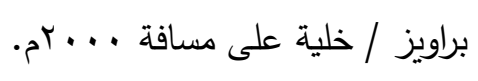

أجريت الدراسة الحالية لمعرفة التأثير الكهرومغناطيسي على حيوية ونثاط نحل العسل خلال شهر مايو من عام

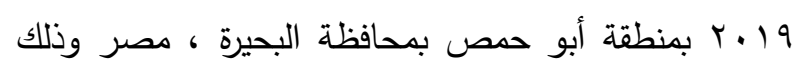

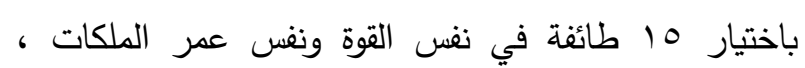
قسمت إلى خمس مجموعات ، كل مجموعة تضم ب طوائف. وضعت المجموعات على أبعاد مختلفة من برج كهربائي

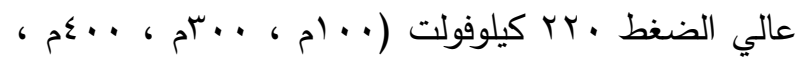

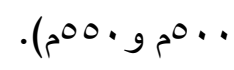

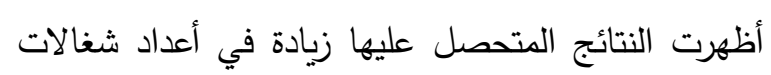

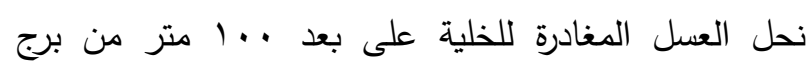
الكهرباء ذي الضغط العالى ، في حين انخفضت تلك الك الأعداد

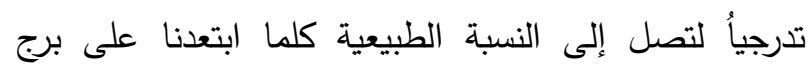

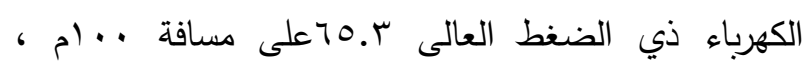

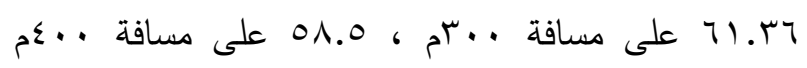

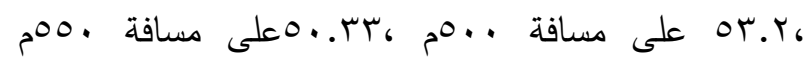

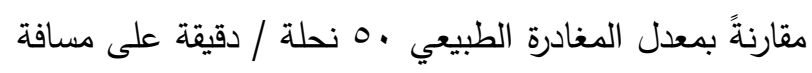

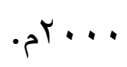
في المقابل ، انخفضت أعداد شغالات نحل العسل العائدة

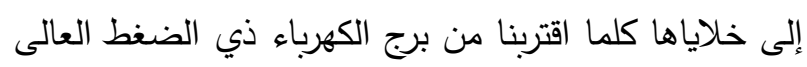

